\title{
Dictionary of arabic and allied loanwords. spanish, portuguese, catalan, galician and kindred dialects
} Leiden - Boston: Leiden, 2008 (Handbook of Oriental Studies, 1, 97) p. XCIII-601. [ISBN 978-90-04-16858-9]

\section{Alessandro Gori}

\section{(2) OpenEdition}

\section{Journals}

Electronic version

URL: http://journals.openedition.org/beo/212

DOI: $10.4000 /$ beo. 212

ISBN: 978-2-35159-318-9

ISSN: 2077-4079

\section{Publisher}

Presses de l'Institut français du Proche-Orient

\section{Printed version}

Date of publication: 1 October 2010

Number of pages: 158-161

ISBN: 978-2-35159-170-3

ISSN: 0253-1623

\section{Electronic reference}

Alessandro Gori, « Dictionary of arabic and allied loanwords. spanish, portuguese, catalan, galician and kindred dialects », Bulletin d'études orientales [Online], Tome LIX | octobre 2010, Online since 01 October 2011, connection on 22 September 2020. URL : http://journals.openedition.org/beo/212 ; DOI : https://doi.org/10.4000/beo.212

This text was automatically generated on 22 September 2020.

(c) Institut français du Proche-Orient 


\section{Dictionary of arabic and allied loanwords. spanish, portuguese, catalan, galician and kindred dialects}

Leiden - Boston: Leiden, 2008 (Handbook of Oriental Studies, 1, 97) p.

XCIII-601. [ISBN 978-90-04-16858-9]

\section{Alessandro Gori}

\section{REFERENCES}

Dictionary of arabic and allied loanwords. spanish, portuguese, catalan, galician and kindred dialects. Leiden - Boston: Leiden, 2008 (Handbook of Oriental Studies, 1, 97) p. XCIII-601. [ISBN 978-90-04-16858-9]

One of the most fascinating situations of linguistic interference in the Mediterranean basin is without doubt that created by the long presence of Arabic in the Iberian Peninsula. The distinguished Arabist and Semitist Professor Federico Corriente (University of Saragossa) has devoted the greatest part of his painstaking scientific activity to the investigation of the history of Arabic in al-Andalus and of its influence on the Iberian languages (especially Castilian). The impressively long list of his achievements in this field has been since decennia the unavoidable reference bibliography for anyone interested in the linguistic and cultural influence of Arabic on Iberian literatures and idioms. In particular, C. edited and linguistically analyzed the famous "cancionero" of the Andalusian poet Ibn Quzmān (Grámatica, métrica y texto del Cancionero hispanoárabe de Aban Quzmán, Madrid, Instituto Hispano-Árabe de Cultura, 1980; El Cancionero hispanoárabe de Ibn Quzman, Madrid, Editora Nacional, 1984; Léxico estándar y andalusí del Diwan de Ibn Quzman, Saragossa, Área de estudios árabes y islámicos de la Facultad de Filosofia y Letras, 1993) and managed to give a 
comprehensive description of Andalusian Arabic (A grammatical sketch of the Spanish dialect bundle, Madrid, Istituto Hispano-Árabe de Cultura, 1977 and, especially, the voluminous Dictionary of Andalusi Arabic, Leiden: Brill, 1997).

Loanwords are perhaps the most apparent manifestation of linguistic contact. The research on the Arabic loanwords in the main Iberian languages and dialects (Castilian, Catalan, Galician, Portuguese) has been a constant interest of $\mathrm{C}$. The coronation of his efforts was the publication in 1999 of the monumental Diccionario de arabismos $y$ voces afines en iberorromance (Madrid, Gredos; a second edition appeared in 2003). The book under review may be basically considered as the English version of that dictionary with some changes and updates.

3 The book is made up of a preface (VII-X), a description of the editorial norms (XI-XIV), a "grammar of Arabic loanwords in Ibero-romance" (XV-LXXXI), an index of the romance lexical items discussed in the "grammar" (LXXXIII), the dictionary of the loanwords (3-480), a first appendix listing the "false Arabic loanwords" (481-492) and a second appendix listing all the foreign words present in the dictionary (493-583). Finally, the copious bibliography (585-601) provides the reader with a useful guide to the existing literature on the topic and proves the complexity of the etymological research in the Ibero-Romance domain.

4 The author's preface bitterly highlights the general ideological pressure which the work of the etymologist must undergo in Spain (but the Iberian country is by no means an isolate case). It is clear that to any nationalistically oriented mind the very idea of linguistic mixture is unbearable. An always supposedly pure national culture (when not even a pure race) should be mirrored by a pure national language: foreign contributions to the lexicon are not welcome, especially when they come from a cultural area which is perceived as far and hostile (and Islam is always a threat, of course!). However, it is also very much patent that etymology alone cannot contrast the narrow-mindedness of some sections of the public opinion and of the political scene (and also, sadly enough, of the intelligentsia). Tracing back the history of a word can say much on the existence of relationships among peoples but the deep nature of these relationships and their developments can be fully assessed only within the frame of an extensive historical research based on a critical evaluation of all the available sources (obviously, etyma may be one of these sources). The polemics on the origin of a word or group of words seems thus to be meaningless outside its proper linguistic environment, as it can just marginally contribute to the reconstruction of the general history of a people and a land.

5 The second section of C.'s volume presents a synoptic description of the main linguistic phenomena (phonetic: pp. XX-LV; morphologic: pp. LV-LXIV; syntactic: pp. LXIVLXXVII) which characterize the Arabic loanwords in the Iberian languages and "the rules that govern their transfer from the source language to target languages". The perhaps most fascinating of these phenomena is the agglutination of the Arabic determinative article al- to the majority of Arabic loanwords in Spanish and Portuguese. C. (pp. LXIV-LXXIII) discusses at length the main opinions on this topic (especially Noll's contribution) and underlines the linguistic and sociologic role played by Berber and Arabs of "Yemenite" origin in the spread of this peculiar feature. Cases of deglutination and false restoration are also analyzed in a synchronical perspective (LXXI-LXXIII). The sociolinguistic aspect of the issue is also duly studied in the frame of 
the interaction of several different dialects, linguistic registers, substrata and adstrata in the Iberian Peninsula in its Islamic period.

6 Coming to the very core of the Dictionary, one cannot help admiring the impressive work done by $\mathrm{C}$. in sorting out a long and critically well equipped list of hundreds and hundreds of items. The huge number of entries of the Dictionary (all of which presented under several phonetic variants) can be explained by the fact that the book contains words of much different stock. Besides 1) Arabic loanwords stricto sensu, which have been accommodated to the vocabulary of Castilian, Portuguese, Catalan and Galician, the book actually includes also 2) loanwords from oriental languages other than Arabic (even when the word did not pass through Arabic to reach Iberoromance: e.g. badistão, basar, café, caracal, caravansará, gat [gato], rabi); 3) hapax legomena (e.g. ajevío, alcotín, cedaquín); 4) unassimilated or not completely assimilated words, including technical terms (e.g: ab, abdal, ágama, Adonai/y, efod, devanagari, mihrab, sife), jargon and secret language expressions (e.g. jagua!, albaire, caire, hanpa, manfla), and other exotisms of various origin (e.g. bagibabo, cadina, chabuco, jaguir, jamadar, mohúr). The present writer is not a professional linguist and thus is not entitled to discuss the reasons justifying such a wide - and apparently very disputable - range of criteria in selecting the material. It is moreover regrettable that the author preferred not to fully clarify the ratio of his selection procedure and limited himself to a few explanatory lines within his "grammar of Arabic loanwords..." (p. XIX-XX).

7 One more cause of perplexity is that only very seldom the author puts the words he is discussing in a clear chronological frame: the source where a lexical item is firstly attested and the time layers on which the whole lexical material should be properly put are almost never stated. This shortcoming gives the way to a sort of "a-chronical" etymology which confuses the reader and partially hinders a full comprehension of the author's etymological reflections.

8 Some proposed etyma seem to be quite daring (e.g. abanto, alimoche, caramba, dado, dansar, gat, guay, loco, olé). I am not in the position to challenge the author's proposals: only linguists well versed in both Arabic and in Ibero-Romance will be able to support or dismiss C.'s theses. In the following, I thus add only some marginal observations on very few entries of the Dictionary from the point of view of Italian which also incorporated an important number of Arabic loanwords.

9 Abracadabra; the most recent etymological Italian dictionary (Alberto Nocentini (con la collaborazione di Alessandro Parenti), L'Etimologico. Vocabolario della lingua italiana, Firenze, Le Monnier, 2010, p. 4) retraces the origin of the word back to a Greek etymon (aúra kat'aúran, spirit for spirit);

10 albacar for the discussion of the etymon in the Dictionary, it would have been useful a reference to Ital. barbacane whose etymology has been analyzed at length by G.B. Pellegrini (lastly in Ricerche, pp. 184-189 where he proposes a derivation from Ar., barbaH probably with a Latin suffixation -anus, -ana);

11 atacar, for the Italian cognate attaccare, Nocentini, L'Etimologico..., p. 79, reconstructs a Germanic origin, through ancient French estache ('stake'), from Frankish *stakka;

12 the word bagibabo,whose etymon was already in Sebastião Rodolfo Dalgado, Glossário Luso-Asiático, vol. I, Hamburg, Helmut Buske Verlag, 1982 (reprint of the 1919-1921 edition) p. 77, could possibly be analyzed as a compound of Persian bäğ ("tribute") and Hindi $b \bar{a} b \bar{u}$ ("civil servant, employee"); 

the Portuguese dictionary of Machado and Morais. The Dictionary derives it from Ethiopic nägasi "synonym of negús" and calls it "a ghost word." Indeed, agacé can be found in Fernão Lopes de Castanheda, Historia do descobrimento e conquista da India pelos Portugueses, vol. III, Lisboa, Typographia Rollandiana, 1833, cp. 96, p. 321. On the basis of this source, the word is mentioned in António de Morais Silva, Grande Dicionário da Língua Portuguesa, vol. I, Lisboa, Editorial Confluencia, $1949^{10}$, p. 446. It is highly probable that agace is the Portuguese reflex of the Gə‘əz and Amharic term așe/ațe, commonly used in addressing the Ethiopian emperor.

Catalan risc (and its cognates, risch, risco, riesgo) is connected by C. with Arabic rizq. The etymological proposal is not new as it can be found already in L. Marcel Devic, Dictionnaire étymologique des mots français d'origine orientale, Paris, Imprimerie Nationale, 1876, p. 194-195 s.v.risque). Currently, the It. cognate rischio is analyzed as a reconstructed vulgar Latin word ${ }^{*}$ resěcu $(m)$ 'reef, cliff' (derivative of resecāre; see Nocentini, p. 1009).

\section{AUTHORS}

\section{ALESSANDRO GORI}

Université de Florence, département de linguistique 